\title{
KEY CAPABILITY AREAS FOR CHANGE IN COLLABORATIVE INITIATIVES
}

\author{
A.C.J. van Rensburg \\ Department of Industrial and Systems Engineering \\ University of Pretoria, South Africa \\ antoniej@up.ac.za
}

\begin{abstract}
Technology has brought major challenges as to how organisations view global markets and customers, and how they operate within their industry value chains. The impact of technology has exposed participants in the market to global markets that previously were beyond their reach. This paper discusses the key capabilities required to manage change in an organisation that operates as a collaborative organisation in an ever-changing business environment. These capabilities are identified and presented in the context of understanding how a "successful" organisation operates, and the key factors to consider when change is implemented in an organisation. In conclusion, the key capabilities should be managed through a business engineering framework to ensure optimal benefit for the organisation.
\end{abstract}

\section{OPSOMMING}

In die afgelope paar jaar het tegnologie groot veranderings teweeggebring vir organisasies oor die manier waarop hulle besigheid doen in hul onderskeie waardekettings. Die impak van tegnologie het selfs veroorsaak dat markspelers blootgestel word aan globale markte wat voorheen buite hulle bereik was. Die artikel beskryf ' $n$ aantal sleutelvermoëns waaroor organisasies moet beskik om in hierdie snel-veranderde omgewing te oorleef. Hierdie vermoëns word beskryf binne die konteks van 'n suksesvolle onderneming, asook die faktore wat in aggeneem moet word wanneer verandering in die organisasie bekend gestel word. Ter afsluiting moet hierdie vermoëns bestuur word binne 'n besigheidsingenieurswese-raamwerk om optimale voordeel vir die maatskappy te lewer. 


\section{INTRODUCTION}

Towards the end of the last century, major hype about technology was driving the global business world. The thinking on these converging technologies and information highways was that they would create vast new open deregulated markets that were wired together and dominated by transformed organisations that were rewriting the rules of business $[6,10]$.

South Africa did not escape this hype, and the fast-selling business thinking was that the local business environment itself was faced with these enormous changes brought along by the quest for global competitiveness through information technology. This included well-known information technology developments such as enterprise resource planning, electronic commerce, and the Internet itself.

In reality, the past five years have seen the crash of dotcom internet companies, a major recession in the United States of America stock market, and the horror of the act of terrorism on 9/11. On the technology front the world experienced the incredible growth of technologies such as Voice over Internet Protocol, wireless communication, broad banding technologies, and the commercialisation of the Internet. In short, the hype that was created before the year 2000 has been replaced by solid business models that have real impact on the way people do business today. These incredible changes, which have taken place in a few short years, show organisations that the pace of change is here to stay - and even more, will have a profound continuing impact on business, as the innovation cycle for technology shortens day by day.

In the traditional organisational paradigm, management aims to align business strategy with business processes, resources, people, and information technology. As technology becomes a major change driver in the business, business processes and technology are fusing together as traditional boundaries disappear [23]. This results in digital business strategies that direct streams of work across traditional organisational, industrial, and even international boundaries to form virtual or collaborative organisations [23].

To deal with these complex systems, business engineering as an engineering approach is applied to move organisations and solutions towards meaningful and capacitated operations. This means that organisational knowledge is formalised and fostered in "collaborative webs" to ensure that economic value-added change interventions take place through a disciplined approach [8]. Not only is this needed, but a number of supporting key capabilities must also be found in the organisation. Some of them are not new, while others change contemporary thinking about the way that organisations are engineered and managed to deliver value-added products and services to customers.

The focus of this paper is to identify and discuss the key capability areas that an organisation needs in a collaborative environment. The basic assumption is that collaborative organisations are more exposed to fast moving changes, and in order to remain successful in such an environment, they need to embrace change formally 
through a disciplined approach. Global experiences and trends show that these arguments and assumptions are generic and applicable to all collaborative initiatives, independent of geographical position or spread.

\section{MANAGING ORGANISATIONAL CHANGE}

At any given time, organisations are under pressure to optimise existing operations, or create new markets to deliver acceptable returns to the shareholders of the organisation. As a result, organisations should, if they have not already done so, consider change initiatives as a formal, integral part of their business strategy and operational activities.

Embarking on the journey of change requires management of change initiatives through a generic life cycle that innovates the new proposal or design, implements the approved solution, and finally improves on the implemented solution. However, a good change plan needs to follow an holistic approach to address all components of the business in an integrated manner through its process, resource, structure, product, and control activities.

To identify and understand key capabilities for managing change, one needs to understand the basis of a "successful organisation", the stakeholder views on the change process, and the critical success factors to be addressed during the change intervention.

\subsection{Stakeholder views on change drivers}

From a stakeholder viewpoint, change initiatives in the organisation are important, since in one way or another they will have a profound impact on the organisation, its shareholders, employees, and the change experts managing change initiatives.

From a shareholder view, changes in the business should not risk cash flow, income statement, balance sheet activities, or the organisation's ability to deliver goods and services to its customers. As good practice, the shareholder wishes to know that the organisation has a good understanding of change and of the inherent risks attached to the proposed change initiative, and that a risk and contingency plan is in place to manage any risks that may stem from implementing these change initiatives.

From an employee view, change efforts impact them, either by being part of the project team, or by being part of the business process that is changed. If the employee has to contribute towards designing, implementing or maintaining a change initiative, it is critical that the employee has an organisational context to operate from. This means that the employee needs to understand and quantify those parts of the business that are being changed in order to ensure that the objective of enhanced organisational performance is achieved.

The change expert deals with the management and delivery of change initiatives in the organisation. In most instances this includes project resource management issues, meeting delivery deadlines, and managing the business case benefits as promised to 
the management team. It is important for the change expert to ensure that the change management process includes all stakeholders, that these stakeholders are informed, and involved as required through the steps of implementation.

If change is introduced through a formal process, significant value will be added if it is managed and controlled in such a manner that the issues of project slip, nondelivery, and bottom-line results are adequately addressed and transparent to all stakeholders.

\subsection{Successful organisations}

To build an understanding of the key capabilities required to support change initiatives, a broad description is presented of how a successful organisation operates. One might think that collaborative organisations, digital business strategies and work streams would make discussion of a structured organisation model unnecessary. In reality, however, well-defined and focused organisations help stakeholders to participate effectively in these collaborative ventures. This build on the basic premise that in order to participate in complex systems, the building blocks ("organisations") that need to be placed into these complex systems need to be understood in structure, functioning, and relationships [20].

A typical successful organisation is a one that is focused, integrated and aligned along its corporate and business strategy to deliver customer value through its organisational capabilities. To achieve this, four key areas need to be addressed: direction setting, customer aligned organisations, organisational capabilities, and finally human resource capabilities. These areas are interdependent, and follow a logical sequential flow as shown in Figure 1.

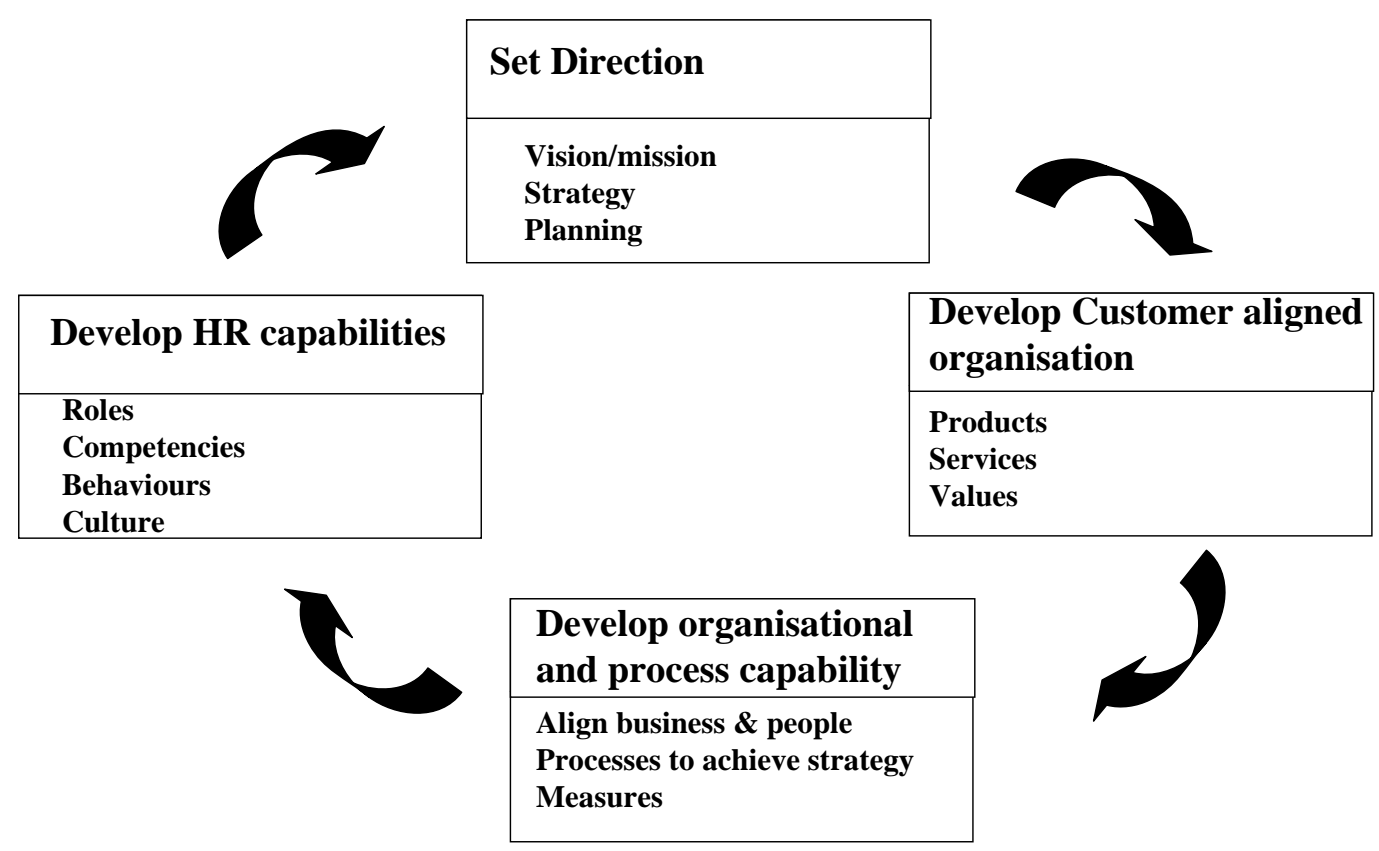

Figure 1: Sequential key areas of a successful organisation 
The key area of setting direction ensures that a clearly articulated vision, mission and strategy are defined for the organisation. Part of this process includes the business planning cycle to address the allocation of priorities and resources for successful implementation. This creates the environment for the organisation to evolve into a customer aligned organisation. In such an environment the emphasis is placed on meeting the needs and wants of its customer base.

Achieving a customer aligned organisation depends on delivering products and services through a suitable and appropriate organisational and process capability. This capability is created through aligning people and resources to the business strategy, and making sure that appropriate metrics are in place to measure operational activities. Finally, a successful organisation develops human resource capability through clearly defined roles, competencies, behaviours, and culture to support the organisation's structures and customers. Making sure that this cycle is aligned and working well establishes the foundation for a successful organisation.

\subsection{Key success factors in change initiatives}

Successful management of change initiatives in an organisation cannot be applied in recipe fashion, since it relies on the application of a number of disciplines, skills, competencies, and capabilities. Thus, a pragmatic philosophical approach should be followed when change is managed in the organisation, guided by a core set of values and principles to ensure successful implementation.

The first success factor is to understand and comprehend the business strategy. In many organisations, business strategy is not clearly understood by the employee, thus making it very difficult for the employee to relate to clear and consistent objectives and performance measures. If an individual employee cannot identify and measure a target within the context of the business strategy, then change and improvement becomes difficult.

The second success factor deals with management information. Management information needs to appear through applications, techniques, and reports to produce a stream of relevant information that supports decision making. In the absence of relevant and applicable information on performance measures, baselines, and performance levels, management of change initiatives becomes virtually impossible.

The third success factor deals with employee capability to understand the context of change, the extent of change, and the risks and impacts to be considered in the change process. If this is lacking in the change initiative, the organisation's ability to change is severely hampered.

The final success factor addresses the organisation's financial information and financial systems. The basic process and system design of the organisation should ensure that financial information is not a lagging indicator in the business, but rather a leading indicator, since financial information ultimately depicts the well-being of the business. This means that financial information design should focus on timeously integrated and well-translated information that depicts bottom-line financial results. 
Again, if this approach and design is lacking, it is difficult to measure the optimisation impact [24].

\section{COLLABORATIVE ORGANISATIONS}

Gartner Group [5] and Future World [6] classify organisations into one of three categories: vertical organisations, hybrid organisations, or collaborative (virtual) organisations. The vertical organisation owns all the process steps in its supply chain, from raw material supply to the final product or service. Hybrid organisations allow third parties to produce certain product or service components for their supply chains. The third and most radical business model - the collaborative (virtual) organisation - emphasises vendor management to source and produce different components of the final product or service. This type of organisation focuses on exploiting what needs to be done, at which specification level, and how third parties fit together in such a "collaborative organisational web” (see figure 2).

To operate a collaborative model successfully, emphasis is placed on customer service, business process outsourcing, information technology, and organisational knowledge. This means that stakeholders need to shift their paradigms with regard to a number of collaborative model aspects.

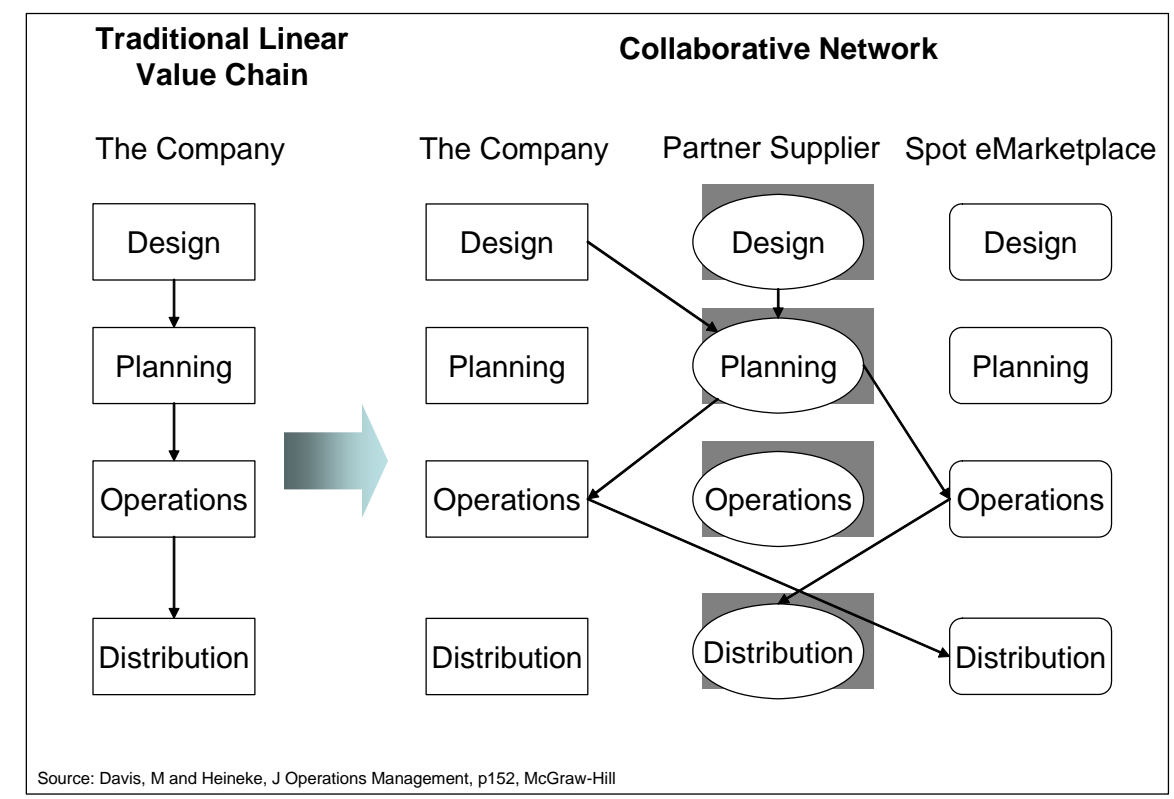

Figure 2: Collaborative networks

These include ownership in the value chain, mass customer management, digital business processes, business process outsourcing, and knowledge as a tangible asset. Table 1 below identifies the original market leaders in such collaborative models that shifted the paradigms of industry business models. 


\begin{tabular}{|l|l|}
\hline Paradigm & Company \\
\hline Mass customer management & Amazon.com - on-line retailing \\
\hline Digital business processes & Charles Swab - on-line stock trading \\
\hline Business process outsourcing & Original Palm Pilot digital assistant \\
\hline Knowledge as a tangible asset & Microsoft share incentive scheme \\
\hline
\end{tabular}

\section{Table 1: Collaborative model components}

As market leaders established the de facto standard for addressing new business models in the collaborative market, supply chain management has emerged as the new driver behind the growth of collaborative organisations. The first wave of emphasis has been on planning and forecasting functions between different organisations, but as a recent study by TerraNova [18] shows, South African companies are still far from making collaboration fully functional. Major obstacles to this have been identified as the lack of integration and flexibility within companies themselves, and even worse, between companies in the collaborative web.

A recent study undertaken by Spalding and Van Rensburg [19] identified a number of key factors that need to be addressed before these collaborative efforts between companies become successful. In essence, the focus is on flexibility, connectivity, and co-ordination of planning activities, that enforces relational integration between all components in organisations in the supply chain. Integration is further supported through engineering business processes towards standardisation, flexibility, and simplification. Finally, commitment and vision is shared between all stakeholders in the collaborative effort through clearly articulated objectives and measures.

In summary, three capabilities enable collaborative organisations to flourish: business processes, change management, and organisational knowledge [21].

\section{BUSINESS ENGINEERING}

In this day and age, successful accomplishment of large-scale change projects in organisations requires a combination of managerial and technical specialties and expertise. In the context of these projects, engineering is concerned with the economical use of limited resources for the benefit of people. Classical engineering focuses mainly on system performance as the main objective, rather than on the development of the overall system of which the product or service is part. Experience in recent decades indicates that a properly functioning system that is competitive cannot be achieved through efforts applied largely after it comes into being [21, 22].

Business engineering is the systems approach to the analysis, design, development, and construction of complex systems, using the business process as the integrative component of the total system. From a systemic thinking perspective, business engineering deals with organisations through a number of key philosophies. First, a top-down approach is followed to view the organisation as a whole system. Second, a life-cycle orientation defines the organisational phases of system design, development, construction, production, distribution, operation, maintenance, support, retirement, phase-out, and disposal. Finally, an interdisciplinary team approach is 
followed throughout the system design, development, and implementation process of the change initiative to ensure that all performance objectives are addressed in an effective and efficient manner [21].

As a systemic approach to designing collaborative organisations, business engineering enables the change expert to deal with all life cycles within the organisation, as well as the basic construction or architecture of the organisation. The life cycles include the design phase of the change initiative in the system, the next cycle of management and planning of the operations in the system, and the final cycle of system improvement. Within these cycles, the construction of the organisation focuses on people, business processes, resources, products, and control activities.

\section{KEY CAPABILITIES}

In summary, collaborative trends, business engineering, successful organisations and change initiatives, design abilities, maintaining and managing collaborative organisations, centre on having three key capabilities in the organisation: process, change, and knowledge. These are developed, supported and expanded upon through a number of assumptions that are driven by the direction and importance of collaborative organisations.

\begin{tabular}{|l|l|}
$\begin{array}{l}\text { Key capability area } \\
\begin{array}{l}\text { Performance } \\
\text { management }\end{array}\end{array}$ & $\begin{array}{l}\text { Objective } \\
\text { Ensure alignment between business and strategy. }\end{array}$ \\
\hline $\begin{array}{l}\text { Knowledge } \\
\text { management }\end{array}$ & $\begin{array}{l}\text { Develops organisational knowledge and the capacity to } \\
\text { act. }\end{array}$ \\
\hline Business architecture & $\begin{array}{l}\text { Define business processes and their relationships with } \\
\text { products, planning and control activities, structures and } \\
\text { resources in the organisation. }\end{array}$ \\
\hline Change management & $\begin{array}{l}\text { Formalised approach to manage and implement change } \\
\text { initiatives through performance measures and project } \\
\text { management activities. }\end{array}$ \\
\hline $\begin{array}{l}\text { Organisational } \\
\text { information dynamics }\end{array}$ & $\begin{array}{l}\text { Support change management and knowledge management } \\
\text { activities in the organisation. }\end{array}$ \\
\hline
\end{tabular}

Table 2: Key capability areas

The first assumption states that business value is generated in an organisation through three types of change initiatives: productivity enhancement, exploitation of existing markets, or the creation of new markets. It is also assumed that these change initiatives occur as a result of leadership which results in the formulation of change strategies and implementation initiatives and plans. To improve and implement effective change initiatives, organisations use methodologies, tools and techniques such as Total Quality Management (TQM), Continuous Improvement (CI), and Business Process Reengineering (BPR). The final assumption is that innovative new solutions for change are primarily the result of organisational knowledge that is 
created in the organisation, based on the understanding and practice of the market place, the business mandate, and internal operations.

These assumptions expand the three originally identified key capabilities to include a broader representation, as shown in Table 2.

\subsection{Performance Management}

Traditionally, organisational performance and well-being are measured through financial performance and measures. According to Kaplan and Norton [9], the main problem with such an approach is that financial measures describe past events in the organisation, lagging behind real causes for certain events. This results in the need to be able to measure and understand the performance and impact of leading indicators that pertain to customers, processes, technology, and employees. The balanced scorecard as a performance management methodology extends the measurement of traditional financial measures into customer measures, process measures, and employee measures [9]. Using financial performance objectives in conjunction with these performance perspectives highlights those objectives and measures that address future performance issues against the background of past performance drivers.

In essence, the balanced scorecard supports the expansion of business objectives beyond financial measures. This allows executives to measure how the organisation is creating value for its customers, and how they need to enhance organisational capability through management of people, systems and processes to improve performance [9].

Based on this approach and methodology, performance management is defined as a discipline and approach that ensures that alignment takes place between the vision, strategy and operations in the organisation. This means that all work done in the organisation by individuals, and by the organisation itself, focuses on contributing to key performance objectives that support business objectives. Business objectives as stated in the organisation strategy are quantified through performance indicators and desired target levels. These performance objectives are grouped together in four balanced scorecard performance perspectives that focus on customers, finances, processes, and human resources. Causality is determined between these performance objectives to show clearly how these performance objectives depend on and influence each other in the course of business. For example, if a call centre operator fails to comply with certain service levels, it may mean that the customer will stop buying the company's products and services, and so the financial performance objective of bottom line profit will be impacted. During the next step, the clusters of performance objectives are allocated to cross-functional teams to ensure that ownership is created for performance delivery in a process fashion rather than a functional fashion. Finally, cross-functional performance requirements are allocated to individual goal sheets to ensure that the individual is aligned and responsible for achieving the organisation's business objectives. 


\subsection{Business Architectures}

Any organisation in any type of industry works because people work in the organisation using different resources. This contextual flow of events and activities forms a pattern that is unique to the organisation and its positioning in the market place. Business architecture is the formal discipline through which a blueprint is developed of the organisation, very similar to the way that a blueprint is developed for a house or building. Typically these blueprints are represented through three basic modelling methods: the function model, process model, and object model [21].

Business architecture is the process of defining the architecture of the organisation in support of the management and optimisation of the organisation [16]. It is an abstract methodology and toolset that defines organisations through horizontal and vertical views, so that the organisation's functions are better understood. Horizontal layers are typically used by the business architect to construct different levels of abstraction of ownership and responsibility in the organisation. For example, the shareholder view of the organisation will normally form the upper horizontal layer in the model, while the operational view (worker) will form the lower level of ownership in the model. Vertical views of the model allow the business architect to describe userdefined views for each horizontal layer. Each of these vertical views will be fully integrated descriptions of functions, processes, strategy, people, networks, and resources.

The combination of the vertical and horizontal descriptive layers creates a model that enables the organisation to have an holistic understanding of how the organisation is constructed and how it functions. This allows change practitioners to use a business architecture model of the organisation in a number of change and optimisation applications, such as enterprise resource planning implementations, business process reengineering projects, and supply chain optimisation [25].

\subsection{Knowledge Management}

Knowledge management originally grew from two different disciplines, information technology and human resources management. Different definitions for these disciplines support current perceptions that knowledge management is a new name for applications such as data warehousing, information management, and performance management. It is argued that knowledge management should rather combine the focus areas of information technology, human resources, general management, and investment management to create a discipline through which value is created from an organisation's non-tangible assets. Non-tangible assets include patents, internal process knowledge, customers, and branding. By actively managing these as real value assets, organisations can increase the organisation's economic value many times over.

The knowledge management objective in any organisation should be to integrate the collective knowledge of the organisation and its employees in such a way that the whole of organisational knowledge is greater than the sum of the individual parts. This will help the organisation to develop its ability to learn and undergo a continual 
process of change - and, by doing so, improve and enhance the performance of the organisation [2].

The application of knowledge management focuses mainly on three types of structures in the organisation [27]. The first is referred to as the external structure, which defines all knowledge about customers and suppliers, and their relationships with the organisation. A typical example of this would be to include suppliers in changing the organisation's own internal policies, procedures and processes with regard to purchasing. The second structure deals with the internal structure of the organisation. This encompasses the internal processes of the organisation, the systems used, and includes, but is not limited to, branding and patents. If an organisation for example decides to standardise all business processes and keep the documentation on-line for all employees to view and use, it will contribute to the internal structure of the organisation. The final structure of knowledge management is internal competencies. Internal competencies refer to the educational level of employees and their collective capabilities. This enables the organisation to formulate policies on how employees will be deployed and helped to grow, while growing the overall ability of the organisation in its business. The "sweet spot" for the organisation is to harness the flow of knowledge between these three structures, resulting in innovative breakthrough strategies and applications. A good example of this is the discovery and commercialisation of cell phone technologies by the Nokia group, which changed it from a local industrial conglomerate to a global mobile handset service company [26].

The three structures, and the flow of knowledge between them, form the organisational content. By actively managing the content of the organisation, the organisation can effectively embrace change and use it to its advantage in the market place.

\subsection{Organisational Information Dynamics}

Organisation Information Dynamics (OID) describes the collective discipline of information management and its applications in the organisation (decision support systems, management information systems, executive information systems, knowledge management, and data warehousing) [15]. OID in this discussion is seen as an important capability that an organisation needs to possess, as it helps it to get the correct information in an organised way to the right people in the right place at the right time. To describe and understand the domain fully would fill many pages, but in summary a stakeholder needs information to assess, understand, and decide on the appropriate course of action to follow - for example, whether performance levels in the organisation need to be addressed by an internal organisational change initiative, or by an external change initiative.

\subsection{Change Management}

Change management is a word that is used in a number of instances when change projects fail. It is usually defined as the approach to assist people in the process of changing themselves in the context of structural change in the organisation. It should 
rather be defined and understood as a formal discipline that deals with organisational change in two dimensions [23, 24]. The first dimension assumes that change activities should be dealt with in the same manner as when an organisation designs products, services and processes. In this case, work activities are formally structured for the phases of the business case, design, implementation, and maintenance of changes in the organisation. These activities deal with changes in organisational processes, structures, resources and governances through project plans, deliverables, time tables, and supporting infrastructure.

The second dimension deals with the "soft" side of change - that is, dealing with the people involved or impacted by change. In this context it will include the previously mentioned groups of stakeholders, but also include external parties such as customers and suppliers. The philosophy is to deal with people in a calculated intervention mode; thus, if it cannot be measured, it cannot be improved. All training and education programmes, communication interventions, organisational development and typically human resource interventions (recruitment, placing, retraining, and exit processes) are focused on the change plan and making sure that change is implemented within acceptable organisational risk parameters. Since people are the most critical factor to ensure implementation success, "people interventions" run in parallel with "work activity interventions" with the appropriate stakeholders in the change life cycle.

Change management in the business engineering context guides the organisation in identifying, planning, and managing change initiatives in the organisation. From this viewpoint change management is based on project management, human resources, and business engineering to create a change management methodology and capability that deals with change in an organised and risk sensitive manner.

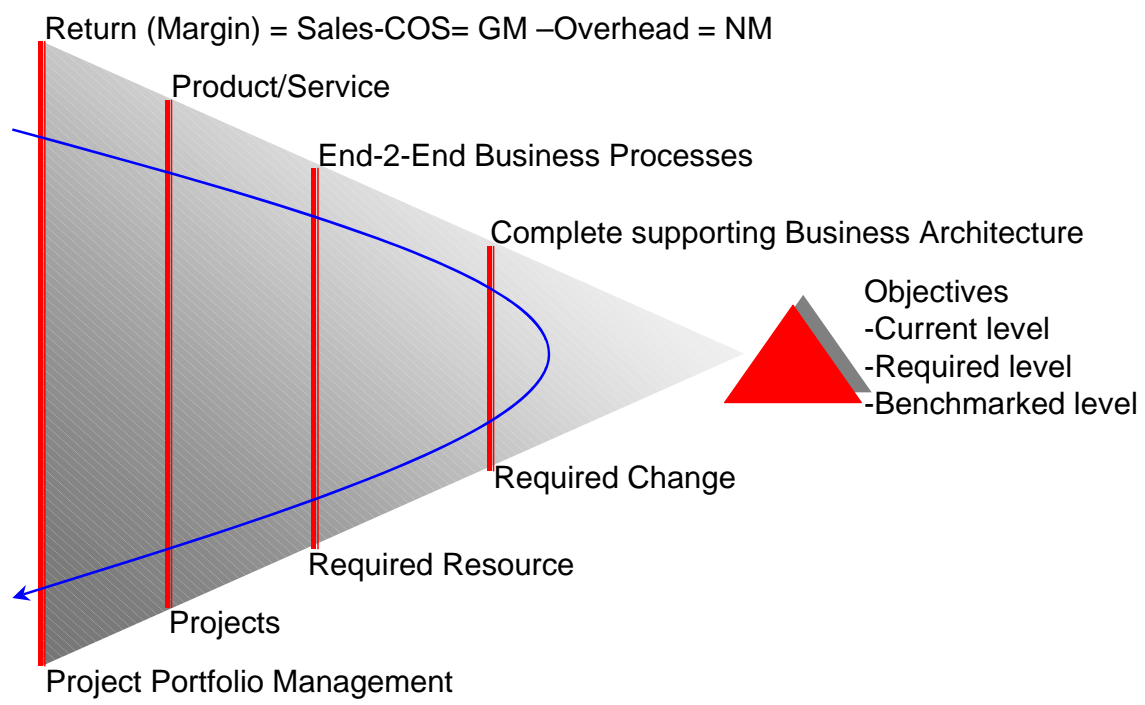

Figure 3: Change management cycle

Figure 3 shows the change management cycle that is followed in designing, implementing, and monitoring change initiatives. The basic premise of this cycle is 
that change is defined as a project that has a defined start and end in the organisation. The key success factor of this approach is to have well-defined performance measurements (customer, financial, process or human resources) as a starting point in the process. These measurements identify the appropriate product and service mix in the organisation's bill of offerings. In turn, through the use of the business architecture capability, the change expert and his/her team can trace the end-to-end business processes that support delivery of the identified product and service mix.

The change initiative will have a best practice performance level, as well as planned performance level. Understanding the existing level of performance for the scoped business processes through OID, a level of change impact can be formulated. This will indicate the severity of change required (e.g. breakthrough or continuous), and the required increase of performance levels. The difference between the existing performance levels and the required performance levels will define the gap that exists between the As-Is situation (current situation), and the To-Be situation (or required situation). Understanding the tolerance of risk in the organisation and the stated gap between the As-Is and the To-Be ensures that a sensible change plan is developed to define the work activities and people interventions required to bridge the gap and successfully implement the change initiative. From the change plan a resource plan is created to ensure that adequate resources are dedicated to the change plan for successful execution. All change plans and resource plans are placed into a portfolio of changes to ensure that optimal co-ordination and alignment of these activities take place across the organisation.

\section{CONCLUSION}

In the few short years since 2000, solid business models have developed from the much-hyped pre-2000 technology models. Technologies such as the Internet, broad band and Voice-Over-IP support the development of collaborative organisations where functions in the supply chain are networked between different entities through different technologies across geographical boundaries. Operating successfully in these environments requires a number of critical elements to be addressed in organisations.

From trends, disciplines and movements on collaboration, business engineering, change management, and successful organisations, the author argues that key capabilities focusing on management of process, change, and knowledge within the organisation are most suited to support change in collaborative environments.

This paper concludes that these key capability areas are vital for an organisation to survive and participate in the global economy, which deals with change in a constant manner. Furthermore, these capabilities should not exist in isolation, but must be implemented within a business engineering framework to ensure that change is defined, implemented, and maintained in a systemic manner - ensuring that the organisation as whole system satisfies the different requirements of stakeholders at the same time. Making sure that this is part of the organisational knowledge ensures that organisations can embrace change and operate successfully in collaborative initiatives across organisational and geographical boundaries. 


\section{REFERENCES}

[1] Amazon.com. http://www.Amazon.com.

[2] Breedt M. and Van Rensburg A. 1999. 'Knowledge Management Principles', Unpublished paper, Department of Industrial and Systems Engineering, University of Pretoria.

[3] Chase and Aquilano. (1995). Production and Operations Management, $7^{\text {th }}$ Edition, Irwin.

[4] Davis, G. (2003). 'IT Portfolio Management', In METAmorphosis, Chicago, Meta Group.

[5] Duncan, W.R. (1996). A Guide to the Project Management Body of Knowledge, PMI Communications, USA.

[6] Future World. http://asp.futureworld.co.za.

[7] Gartner Group. (1999). 'New Challenges for the IT Executive', Conference Presentation.

[8] Hammer, M. (1990). 'Reengineering Work: Don't Automate, Obliterate', Harvard Business Review. July-August, pp 104-112.

[9] Kaplan, R.S. and Norton, D.P. (1996). The Balanced Scorecard, Harvard Business School Press, USA.

[10] Pascale R., Milleman M., Gioja L. 1997. Changing the way we change. Harvard Business Review. 127-139. November-December.

[11] Pennypacker, J and Sepate, P (2002), Project Portfolio Management and the Strategic Project Office, Issue 2, Portfolio Knowledge, USA.

[12] PQBC. (1998). Change Management training course. Persetel-Qdata Business Consulting.

[13] Pycraft, M. et al. (2002). Operations Management, Pitman Publishing, South Africa.

[14] Render, B. and Stair, R.M. (1995). Quantitative Analysis for Management (Fourth Edition), Allen and Bacon, pp 20-21.

[15] South African Micro-Finance Business Plan (SAMAF). (2005). The Department of Trade and Industry, South Africa.

[16] Spewak, S. (1993). Enterprise Architecture Planning, Johan Wiley and Sons, pp 1-2.

[17] Stonebraker, P.W. and Leong, G.K. (1994). Operations Strategy, Allen and Bacon.

[18] TerraNova (2005). Supply Chain Foresight Study 2005, Sunday Times, 20 March.

[19] Spalding, R and Van Rensburg, A. (2005). MBA Research Project, Wits Business School, University of the Witwatersrand.

[20] Van Rensburg, A. (1996), An Open Solution Methodology to Problem Solving, PHD Thesis, University of Pretoria.

[21] Van Rensburg, ACJ. (1998). A Framework for Business Process Management. Journal of Computers and Industrial Engineering. 35. 1-2. pp 217-220.

[22] Van Rensburg, ACJ. (1999). Programme in Industrial Engineering. Department of Industrial Engineering, University of Pretoria.

[23] Van Rensburg, A. (1999). 'Industrial Engineering Disciplines for the Next Millennium', 26 ${ }^{\text {th }}$ International Conference on Computers \& Industrial 
Engineering, Melbourne, Australia, 15-17 December.

[24] Van Rensburg, A. (2005). 'An Enterprise Portfolio Approach for the Management of Operational Improvement Strategies', EUROMA International Conference on Operations and Global Competitativeness, Budapest, Hungary 19-22 June.

[25] Venkatraman K and Henderson JC. Fall 1998. 'Real strategies for virtual organizing’. Sloan Management Review. pp 33-47.

[26] www.nokia.com, 2005.

[27] www.sveiby.com, 2005. 